\title{
Cluster Analysis of Ranunculus Species
}

\author{
S U R A N TO \\ Biology Department, Faculty of Mathematics and Sciences, Sebelas Maret University Surakarta 57126.
}

Received: 5 May 2001. Accepted: 31 July 2001

\begin{abstract}
The aim of the experiment was to examine whether the morphological characters of eleven species of Ranunculus collected from a number of populations were in agreement with the genetic data (isozyme). The method used in this study was polyacrilamide gel electrophoresis using peroxides, estarase, malate dehydrogenase, and acid phosphatase enzymes. The results showed that cluster analysis based on isozyme data have given a good support to classification of eleven species based on morphological groups. This study concluded that in certain species each morphological variation was profit to be genetically based.
\end{abstract}

(c) 2002 Jurusan Biologi FMIPA UNS Surakarta

Key Words: Ranunculus, isozyme

\section{INTRODUCTION}

Cluster Analysis has been widely used in studies of plant variation. Examples include Weis and Simmons (1979), Moran and Hooker (1983), Potts and Reid (1985b), Wittshire and Reid 1987, Menadue 1986. This method allows use of a number of phenetic variables in addition to cytological or genetic variables (Togan et. al., 1983).

This analysis method using isozyme data has been shown to be quite valuable in providing better results to examine interrelationships between similar or different ploidy levels in plants. In the tetraploid plants Glycine tomentella, cluster analysis using isozyme data has been proved to be valid in grouping the species based on geographical origin of accessions (Doyle and Brown, 1985).

A number of different methods of cluster analysis have been employed recently in plant taxonomic studies, particularly in studies of lower level ranks of plant taxonomy, i.e. species or sub-species. Three of these are the weighted pair group method using averages (WPGMA), the unweighted pair group method using the centroid (UPGMC), and the unweighted pair group method using averages (UPGMA).
These different sorts of cluster analysis provide techniques to distinguish or define samples (plants) based on the dissimilarities between the groupings in the field (Sneath and Sokal, 1973).

Results of cluster analysis are mainly presented in the form of a dendrogram, which gives a clear position of each population sample indicated by the dissimilarity measure, for instance; the Euclidean Distance (D) or Squared Euclidean Distance $\left(D^{2}\right)$ or Mahalanobis Distance.

\section{MATERIALS AND METHODS}

\section{Plant materials}

Plants from seven populations around the Central Plateau, Tasmania were examined electrophoretically. The collected plants were identified with manuals of Bentham and Hooker (1865), Candole (1818-1821), Curtis (1956; 1967), Curtis and Morris (1975), Hooker (1982), and Menadue and Crowden (1989). Electro-phoresis procedures used were further explained in the next pages. Table 1 gives the location sites and the number of plants used in this study. 
Table 1. Ranunculus species and population sources used for electrophoresis.

\begin{tabular}{llc}
\hline \multicolumn{1}{c}{ Population } & \multicolumn{1}{c}{ Species } & $\begin{array}{c}\text { Plant } \\
\text { number }\end{array}$ \\
\hline Liawenee & R. triplodontus & 16 \\
Nive River & R. triplodontus & 20 \\
Rats Castle & R. triplodontus & 15 \\
Clarence Weir & R. triplodontus & 20 \\
Ouse River & R. triplodontus & 13 \\
Projection Bluff & R. triplodontus & 10 \\
Wild Dog Plains & R. triplodontus & 12 \\
Wild Dog Plains & R. jugosus & 12 \\
Black Mary Plains & R. pimpinellifolius & 9 \\
Pine lake & R. gunnianus & 6 \\
Lake Agusta & R. gunnianus & 5 \\
Projection Bluff & R. decurvus & 10 \\
Rats Castle & R. decurvus & 10 \\
Projection Bluff & R. collinus & 10 \\
Rats Castle & R. collinus & 10 \\
Wild Dog Plains & R. collinus & 10 \\
Hasselwood Lagoon & R. glabrifolius & 12 \\
Lake Crescent Road & R. glabrifolius & 12 \\
Liawenee & R. pascuinus & 10 \\
Wild Dog Plains & R. amphitricus & 10 \\
Green View & R. lappaceus & 9 \\
Wild Dog Plains & R. nanus & 20 \\
Cameron Lagoon & R. nanus & 20 \\
Saint Patrick Plains & R. nanus & 20 \\
Ouse River & R. nanus & 20 \\
Clarence Weir & R. nanus & 20 \\
\hline & &
\end{tabular}

\section{Gel preparation}

In order to make the best quality of polyacrylamide gel, both two kind of stock solutions were prepared. Stock solution A was made by diluting 4,5 grams of TRI (Hydroximethyl) Methylamine (PURISS) and 0,51 grams of citric acid into $500 \mathrm{ml}$ deionized water, while the Stock solution $B$ was prepared by mixing the 30 grams of Acrylamide and 0.80 grams of NN-Methylene-Bis-Acrylamide into $100 \mathrm{ml}$ of deionized water.

\section{Casting the gel}

Mixing $20 \mathrm{ml}$ of solution $B$ and $40 \mathrm{ml}$ of solution $A$ made the gel. This mixture was deaerated on a Buchi rotary evaporator for 5 minutes after which $0,04 \mathrm{ml}$ of $\mathrm{N}, \mathrm{N}, \mathrm{N}^{\prime}, \mathrm{N}^{\prime}$ Tetramethyl-ethylenediamine was added and with carefully mixed. To polymerize the gel, 0,06 grams of Ammonium persulphate was added and mixed carefully immediately before pouring the solution into gel mould (BIO-RAD Model 361). Using this model, at least 4 thin gels each with 10-14 slots can be cast simultaneously.

\section{Protein extracting solution}

Diluting 0,018 grams of cysteine made up the solution of protein extraction. 0,021 grams of ascorbic acid and 5 grams of sucrose into $20 \mathrm{ml}$ of borax buffer $\mathrm{pH} 8.4$.

\section{Extraction and loading the samples}

Laminas and petioles were examined separately. Material from each plant was ground individually in a staining dish using $0.15-0.35 \mathrm{ml}$ of protein extracting solution for laminas and 0, 1-0.15 ml for petioles. Despite the voluminous literature on extraction methodology which suggests the need to use frozen plant material (liquid nitrogen), it was found unnecessary for the systems studied in this project to use other than an ice cool buffer and hold plant material and extracts in a ice bath. The extracts were transferred to a small glass vial, $2 \mathrm{~mm}$ diameter, $3 \mathrm{~cm}$ long, and centrifuged at $3500 \mathrm{rpm}$ for 15 minutes. The supernatants were then applied in the gel slots. The amount of sample loaded in each slot was for peroxidase about 10-15 ul, while for the other enzymes about 15-24 ul.

\section{Electrophoresis}

The electrophoresis chamber used in this project was a mini vertical slab cell manufactured by BIO-RAD, USA. model 360. This model has advantages in allowing use of very small amounts of samples, as well as allowing a short running time

Electrophoresis was conducted at a constant current of $5 \mathrm{~mA}$ for peroxidase (PER) and $7 \mathrm{~mA}$ for esterase (EST), malate dehydrogenase (MDH), and acid phosphatase (ACP), at room temperature for about 60 minutes including a pre-electrophoresis time of approximately 10 minutes. Electrophoresis was stopped when the bromophenol blue marker dye had traveled about $56 \mathrm{~mm}$ from the slot toward the anode.

\section{Staining procedures:}

Four enzymes staining were used routinely.

1. Peroxidase (PER) was prepared by diluting 0.0125 grams of O-dianisidine into $25 \mathrm{ml}$ of acetone. Then $50 \mathrm{ml}$ of $0.2 \mathrm{M}$ acetate buffer $\mathrm{pH} 4.5$ was added and 2 drops of $\mathrm{H}_{2} \mathrm{O}_{2}$ lastly given. 
2. Esterase (EST) was prepared by dissolving 0.0125 grams of $\alpha$-naphthyl acetate in $2.5 \mathrm{ml}$ acetone. After that $50 \mathrm{ml}$ of $0.2 \mathrm{M}$ phosphate buffer $\mathrm{pH} 6.5$ and 0.0125 grams of Fast Blue BB Salt were added.

3. Malate dehydrogenase $(\mathrm{MDH})$ was made up by mixing $15 \mathrm{ml}$ of $0.1 \mathrm{M}$ Tris- $\mathrm{HCl} \mathrm{pH} 8$ and 0.020 grams of MTT (2.5-Diphenyl tetrazolium Bromide) and 0.005 grams of PMS (Phenazine-Methosulfate) into $125 \mathrm{ml}$ of deionized water. Mixed them gently and then $10 \mathrm{ml}$ of $0.2 \mathrm{M}$. Sodium Malate $\mathrm{pH} 7,5$ was lastly added. The gel was incubated for 30-40 minutes in the dark. A fresh solution containing 0.020 grams of NAD (Nicotinamide Adenine Dinucleotide) was used to transfer the gel.

4. Acid phosphatase (ACP) was made by diluting 0.0125 grams of of $\alpha$-naphthyl phosphate into $2.5 \mathrm{ml}$ of acetone and then $75 \mathrm{ml}$ of $0.2 \mathrm{M}$ acetate buffer $\mathrm{pH}$ 4.5. 0.025 grams of Fast Beach K Salt and 0.025 grams were gently mixed.

All staining procedures in this experiment were conducted at room temperature. For peroxidase and esterase stains refer to Mills and Crowden (1968), for malate dehydrogenase stains refer to Brown et al (1978), and for acid phosphatase stains refer to Adam and Jolly (1980).

\section{Cluster analysis}

Data used in this cluster analysis were isozyme band numbers. The bands were treated as characters, by giving values of 1 and 0 to indicate presence (i.e. detectable) and absence (i.e. not detectable) of bands, respectively.

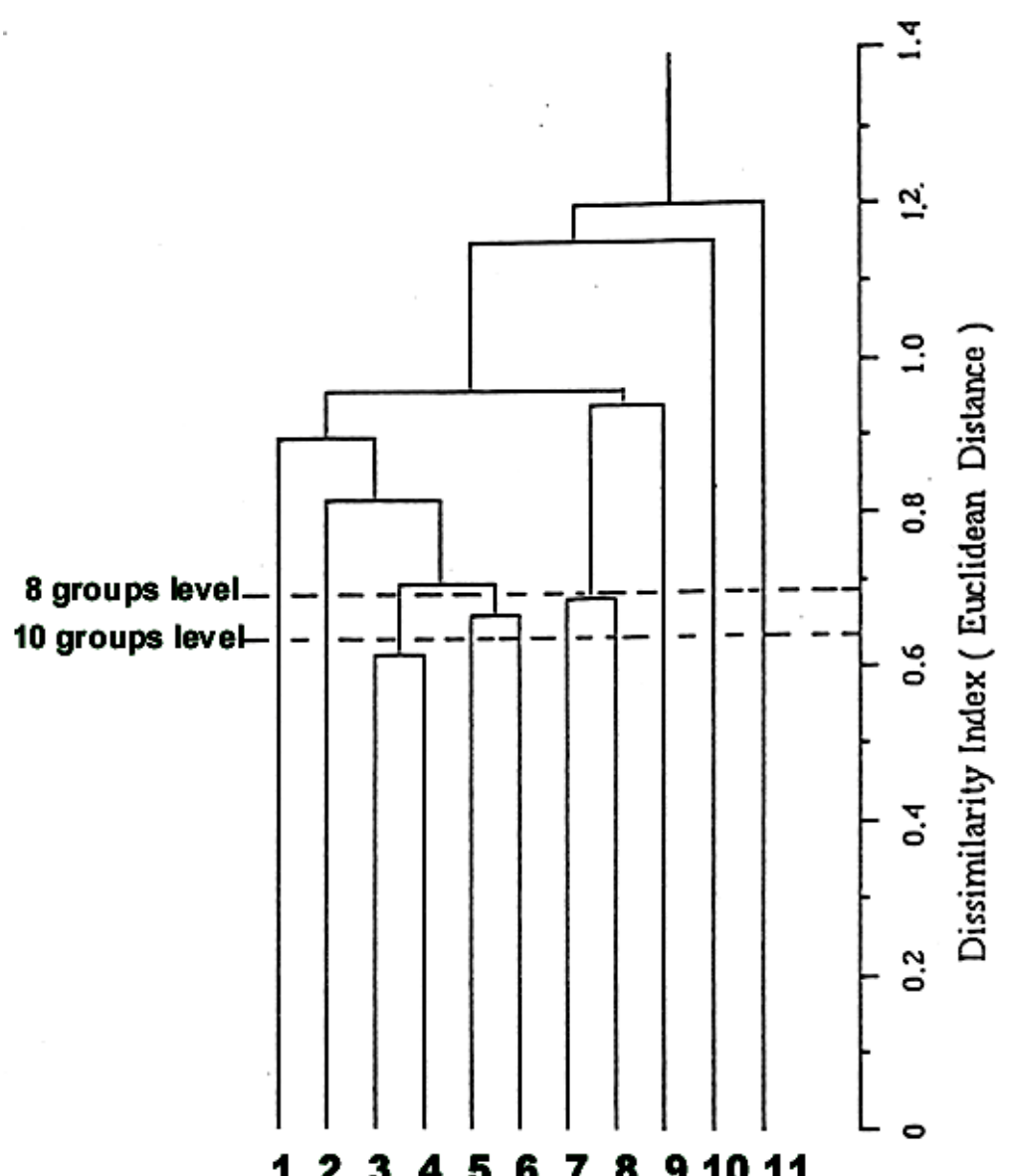

1234567891011

Figure 1. Average linkage of UPGMA clustering eleven species of Ranunculus. Squared Euclidean Distance to measure dissimilarity based on band frequency of PER, EST, MDH, and ACP. Annotations: $1 . R$. decurvus, $2 . R$. amphitricus, 3. $R$. triplodontus, 4. $R$. jugosus, 5 R. pimpinellifolius, 6. $R$. pascuinus, 7. $R$. collinus, 8. $R$. glabrifolius, 9. $R$. gunnianus, 10. R. lappaceus, 11. R. nanus. 
There were 31 enzymic characters, 7 isozyme bands of peroxidase, 9 of esterase, 6 of malate dehydrogenase and 9 of acid phosphatase.

A total of 341 individual plants belonging to the 11 species from a number of populations around the Central Plateau, Tasmania (Table 1.) were scored with respect of 31 enzymic characters, 7 isozyme bands of peroxidase, 9 of esterase, 6 of malate dehydrogenase, and 9 of acid phosphatase.

The data were then computed using the SAS program. The clustering strategy was Average linkage Cluster Analysis using Squared Euclidean Distance (UPGMA).

\section{RESULTS AND DISCUSSION}

Clusters are shown in the dendrogram (Figure 1). At the eight groups level in the dendrogram, an excellent correspondence with the currently accepted taxonomy of these 11 species of Ranunculus was obtained. Only $R$. pimpinellifolius and $R$. pascuinus are not separated as was hoped. It has revealed as distinct species, $R$. decurvus, $R$. amphitrichus, $R$. gunnianus, $R$. nanus, and $R$. lappaceus, and showed the close relationships between species pairs, $R$. glabrifolius- $R$. collinus, and $R$. triplodontus- $R$. jugosus. However the dissimilarity measure at this level is small.

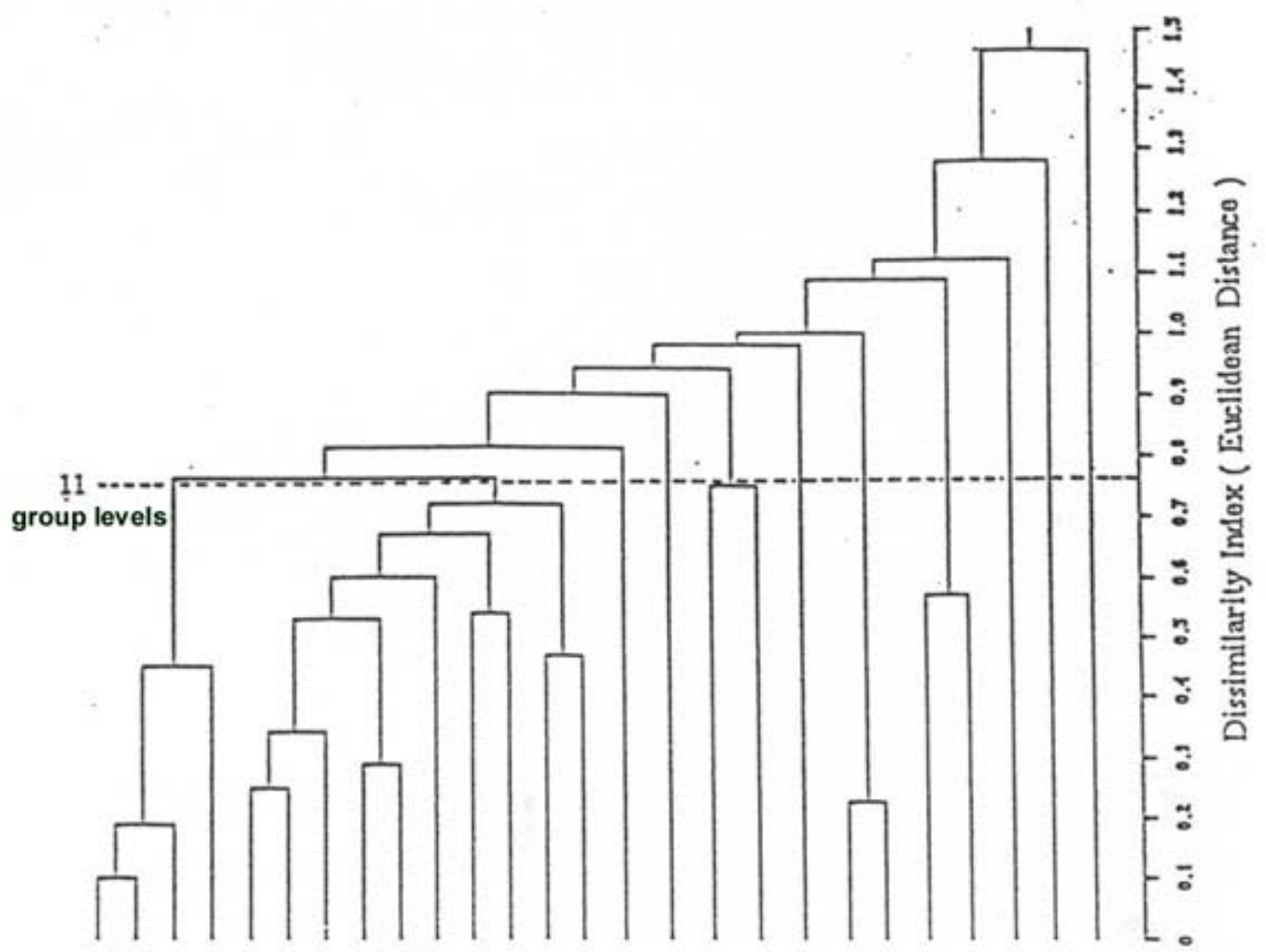

AB D C F G LP QS NM J I K HUT OZY V WER X

Figure 2. Average linkage of UPGMA clustering population of Ranunculus species. Squared euclidean distance to measure the dissimilarity based on band frequency of PER, EST, MDH, and ACP. Codes in the brackets indicate the population site. Annotations:
A. R. glabrifolius (HwL)
B. R. glabrifolius (StR)
C. R. collinus (PBf)
D. R. collinus (WDP)
E. R. collinus (RCs)
H. R. triplodontus (Lwn)
F. R. triplodontus (NRv)
G. R. triplodontus (ORv)
K. R. triplodontus (PBf)
I. R. amphitricus (WDP)
J. R. triplodontus (CWr)
N. R. pimpinellifolius (BMP)
L. R. triplodontus (RCs)
M. R. nanus (SPP)
Q. R. jugosus (WDP)
O. R. nanus (CWr)
P. R. triplodontus (WDP)
T. R. lappaceus (GVs)
R. R. nanus (ORv)
S. R. nanus (CLg)
V. R. decurvus (PBf)
$\mathrm{Y}$. R. gunnianus $(\mathrm{LAg})$
W. R. decurvus (RCs)
Z. R. gunnianus (PLk)
U. R. pascuinus (Lwn)
X. R. nanus (WDP) 
At the ten groups level, the species $R$. pimpinellifolius and $R$. pascuinus were resolved, as were $R$. glabrifolius and $R$. collinus. However, the closely related $R$. jugosus and $R$. triplodontus were still united.

The results of this analysis give generally good support to the classification of these 11 species based on morphological grounds. A second analysis was carried out in which all the different populations were included separately. The results were presented in Figures 2 and 3. Figure 2. shows the grouping of species based on Euclidean Distance clustering strategy. At the 11 groups level, $R$. collinus and $R$. glabrifolius (2 populations of each) from a neat cluster, but a 3rd population of $R$. collinus (Rats Castle) was quite remote from them. The second big branch of the tree consists of $R$. triplodontus mixed with $R$. pimpinellifolius, $R$. amphitrichus and $R$. nanus. The close relationship between $R$. triplodontus (Wild Dog Plains) and $R$. jugosus (Wild Dog Plains) was maintained. Both $R$. gunnianus (2 populations) and $R$. decurvus (2 populations) were separately clustered, while $R$. pascuinus and $R$. lappaceus shared one group. Both $R$. nanus and $R$. triplodontus were scattered into several different groups. This indicates that in both these species, there is considerable "between-population" variation, which may swamp between-species variation.

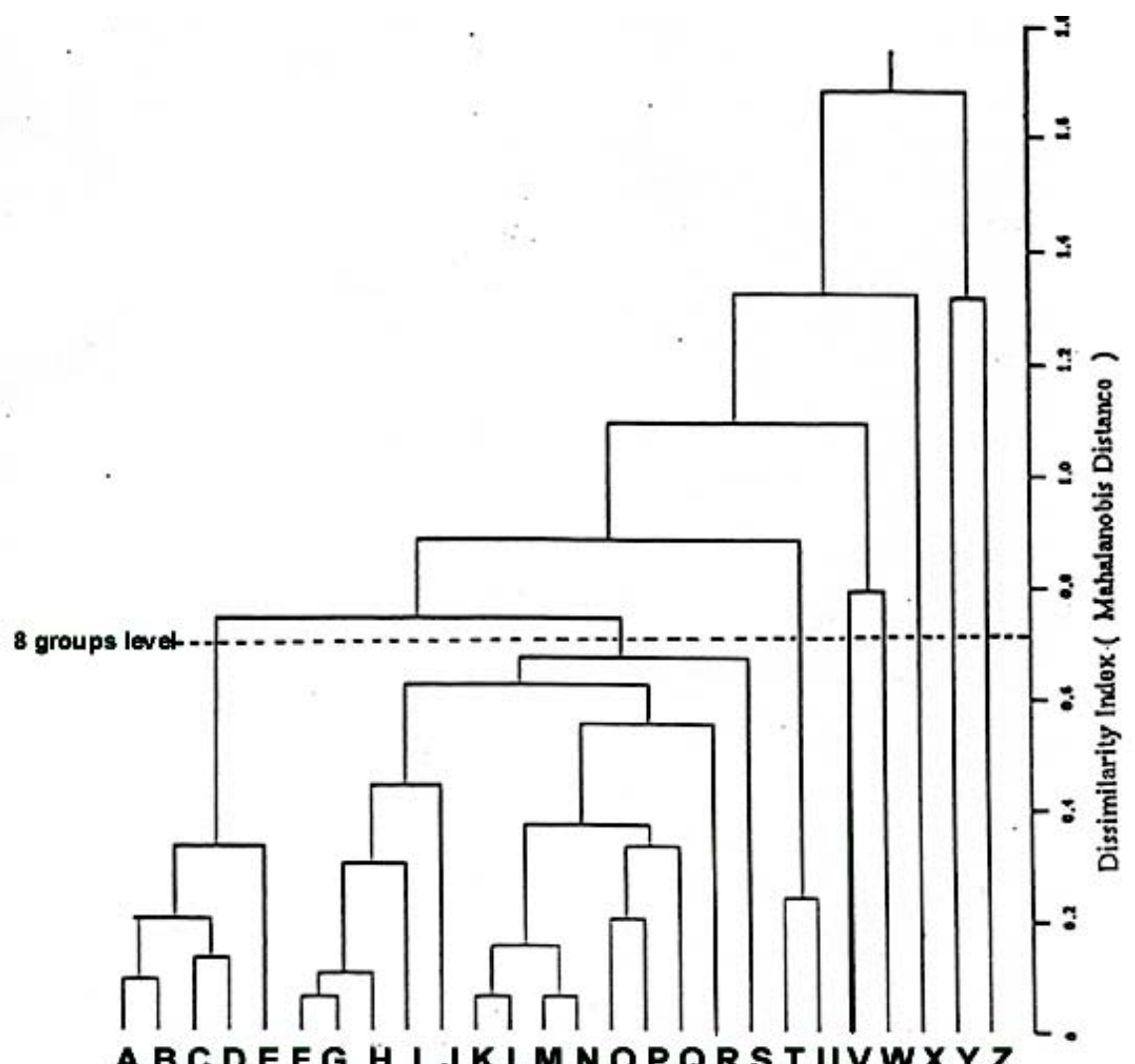

Figure 3. Average lingkage of UPGMA clustering population of Ranunculus species. Mahalanobian distance to measure the dissimilarity derived from non parametric multiple discriminant function analysis: based on band frequence of PER, EST, MDH, and ACP. Codes in the brackets indicate the population site.
A. R. glabrifolius (HwL)
B. R. glabrifolius (StR)
C. R. collinus (PBf)
D. R. collinus (WDP)
E. R. collinus (RCs)
F. R. triplodontus (NRv)
G. R. triplodontus (ORv)
H. R. triplodontus (Lwn)
I. R. amphitricus (WDP)
J. R. triplodontus (CWr)
K. R. triplodontus (PBf)
L. R. triplodontus (RCs)
M. R. nanus (SPP)
N. R. pimpinellifolius (BMP)
O. R. nanus (CWr)
P. R. triplodontus (WDP)
Q. R. jugosus (WDP)
S. R. nanus ( $\mathrm{CLg})$
V. R. decurvus (PBf)
T. R. lappaceus (GVs)
R. R. nanus (ORv)
W. R. decurvus (RCs)
$\mathrm{Y}$. R. gunnianus $(\mathrm{LAg})$
U. R. pascuinus (Lwn)
X. R. nanus (WDP) 
Comparing the Euclidean strategy with the use of Mahalanobis Distances (Figure 3), it appears that the latter provides a neater grouping of the species populations. At the eight groups level the closely related $R$. collinus (3 populations) and R. glabrifolius ( 2 populations) form one cluster. $R$. decurvus and $R$. gunnianus each form a cluster, while $R$. lappaceus and $R$. pascuinus share one cluster. The major cluster contained the other species, with $R$. nanus and $R$. triplodontus spread through the minor sub-groupings.

\section{CONCLUSION}

On the basis of these data, there is no evidence to support Menadue's notion that $R$. collinus and $R$. glabrifolius might be united into a single species. Their close relationship is shown in that they cluster closely in the dendrogram, but always in discrete subgroupings. However, there is sample support for the hypothesis that some populations of $R$. nanus (Menadue and Crowden, 1990) and probably $R$. triplodontus also, are genetically different. This is explored further in the following sections.

\section{REFERENCES}

Adam and Jolly. 1980. Electrophoretic buffer system and stain recipes. In CSRIO, Division of Forest Research (Ed.). Sydney: CSIRO.

Bentham, G and J.D. Hooker. 1865. Genera Plantarum. Volume I. London: Reive $\mathrm{Br}$. Co.

Brown, A.D.H., E. Nevo, D. Johary and O. Dagon. 1978. Genetic variation in natural populations of wild barley (Hordeum spontaneum ). Genetica 49 (2/3): 97108.

Candole, A.P. de. 1818-1821. Regni Vegetabilies Systema Naturale. Two Volumes. Paris: Treuttel et Wurtz.

Curtis, W.M. 1956. A Student's Flora of Tasmania. Part I. Hobart: Government Printing.

Curtis, W.M. 1967. Introduction in the Endemic Flora of Tasmania. London: Airel Press.
Curtis, W.M. and D.J. Morris. 1975. A Student's Flora of Tasmania I. $2^{\text {nd }}$ edition. Hobart: Government Printing. Doyle, M.J., J.E. Grant, and A.H.D. Brown. 1986. Reproductive isolation berween isozyme groups of Glycine temontella (Leguminaosae) and spontaneus doubling in their hybrids. Australian Journal of Botany 34: 532-535.

Hooker, J.D. 1982. The Flora of British India Volume I. Ranunculaceae to Sapindaceae. New Delhi: Bishen Sing Mahendra PA Sing Pub.

Menadue, $Y$ and R.K. Crowden. 1989. Tasmanian species of Ranunculus. A New Key Paper and Proceedings of the Royal Society of Tasmania. Volume 123: 87-96.

Menadue, Y. 1986. Taxonomy of genus Ranunculus in Tasmania. PhD Thesis. Tasmania: New Castle University.

Menadue, Y. and R.K. Crowden. 1990. Leaf polymorphism in Ranunculus nanus Hook. (Ranunculaceae). New Phytol. 114: 265-274.

Mills, A.K. dan R.K. Crowden. 1968. Distribution of soluble proteins and enzymes during early development of Pisum sativum. Australian Journal of Biological Science 21: 1131-1141.

Moran, G.F. and S.D. Hooker. 1983. Genetic diversity and the insular population structure of the rare granite rock species, Eucaliptus casia Benth. Australian Journal of Botany 31: 161-172.

Moran, G.F., J.C. Bell, and S. Prober. 1990. The utility of isozyme in systematics of some Australian tree groups. Australian Systematic of Botany 3: 47-57.

Post, D.M. 1983. Contribution to chromosome number atlas of the New Zealand Flora 26 - Gentiana (Gentianaceaea). New Zealand Journal of Botany 21: 229.

Sneath, P.H.A and R.R. Sokal. 1973. Numerical Taxonomy. San fransisco: W.H. Freeman and Co.

Togan, L. N. Aydem, and A. Kence. 1983. A numerical taxonomic study Carthamus L. Taxa in Turkey. Felsenstain, J. (ed.). Berlin: Springer-Verlag.

Weis, T.W. and D.M. Simmons. 1979. Variation in Australian and some overseas population Emex australis and Emex spinosa. Australian Journal of Botani 27: 631-641.

Wiltshire, R.J.E. and J.B. Reid. 1978. Genetic for variation in the spining gum, Eucalyptus perriana $F$. Muell. Ex. Rodway. Australian Journal of Botani 35: 33-47. 